\title{
Thiazolidinediones: metabolic actions in vitro
}

\author{
C. Fürnsinn, W. Waldhäusl \\ Department of Medicine III, Division of Endocrinology and Metabolism, University of Vienna, Austria
}

\begin{abstract}
acids and peptide hormones. The second states that TZDs improve glucose homeostasis independently To unravel the molecular mechanisms and the causal chain of how thiazolidinediones (TZDs) affect glucose homeostasis, it is helpful to analyse their direct influence on isolated specimens of fat, muscle, and liver in vitro. Studies on isolated adipocytes have shown that the nuclear peroxisome proliferator-activated receptor- $\gamma$ (PPAR $\gamma)$ is an important molecular target for TZDs, through which they trigger adipocyte differentiation and adipose tissue remodelling. It is not clear, however, if the activation of PPAR $\gamma$ in adipose tissue is the cause of all the metabolic actions of TZDs. Based on in vitro studies, two hypotheses have been developed. The first emphasizes PPAR $\gamma$ from adipose tissue actions by the direct interaction with muscle and liver. This hypothesis is supported by direct TZD actions on fuel metabolism of skeletal muscle and liver in vitro, which seem to be independent from PPAR $\gamma$ signalling. Major progress has been made in understanding the mechanisms involved in the effects of TZDs on adipose tissue but the causal chain responsible for their antihyperglycaemic action is still not clear. The involvement of other molecular targets in addition to PPAR $\gamma$, of adipocyte-derived messengers, and of direct interaction with skeletal muscle and liver have yet to be clarified. [Diabetologia (2002) 45:1211-1223]
\end{abstract} mediated actions on adipose tissue, suggesting that insulin sensitization of skeletal muscle and liver is triggered indirectly by changes in circulating concentrations of adipocyte-derived non-esterified fatty

Keywords Thiazolidinedione, peroxisome proliferatoractivated receptor- $\gamma$, in vitro, adipose tissue, skeletal muscle, liver.

Thiazolidinediones (TZDs) are increasingly important in the treatment of Type II (non-insulin-dependent) diabetes mellitus. Troglitazone was the first TZD approved for treating Type II diabetes but it was with-

Received: 17 December 2001 / Revised: 3 May 2002

Published online: 5 July 2002

C) Springer-Verlag 2002

Corresponding author: C. Fürnsinn, $\mathrm{PhD}$, Department of Medicine III, Division of Endocrinology and Metabolism, Währinger Gürtel 18-20, 1090 Vienna, Austria, Europe, E-mail: clemens. fuernsinn@akh-wien.ac.at

Abbreviations: C/EBP, CCAAT/enhancer binding protein; PPAR, peroxisome proliferator-activated receptor; PPRE, peroxisome proliferator response element; RXR, retinoid $\mathrm{X}$ receptor; SPPARM, selective peroxisome proliferator-activated receptor modulator; TZD, thiazolidinedione

drawn from the market because of its detrimental hepatic side effects $[1,2]$. Other TZDs, rosiglitazone and pioglitazone, are now available and are not toxic to the liver $[3,4]$. At present, additional compounds of this class are under preclinical evaluation.

The structural characteristic common to all TZDs is a thiazolidinedione ring, to which divergent molecular moieties are attached (Fig. 1). Because different TZDs as well as compounds with structures resembling the thiazolidinedione ring (e.g., isoxazolidinediones, oxadiazolidinediones; Fig. 1) carry comparable antidiabetic potentials, the thiazolidinedione ring is assumed to relate to antihyperglycaemic TZD action, whereas the substituted moieties seem to modulate pharmacokinetic and pharmacodynamic properties.

The glucose lowering action of TZDs depends on the presence of insulin. Insulin-deficient rats treated 
Thiazolidinediones:

Troglitazone

Rosiglitazone

Pioglitazone

KRP-297

RWJ 241947

(= MCC-555)

NC-2100

proved ability of insulin to suppress glucose appearance, which is basically a function of the liver, was observed in most $[7,8,9,10,11]$ but not all $[12,13$, 15] clamp studies. Hence, TZD treatment amplifies the effects of insulin on the most important tissues of carbohydrate metabolism including muscle, liver, and fat. Skeletal muscle, being the primary target tissue for insulin-stimulated glucose disposal [20, 21], plays the quantitatively predominant role in TZD-dependent glucose lowering [7, 12, 13, 15, 17, 22].

Although metabolic changes caused by prolonged TZD treatment have been thoroughly described in vivo and ex vivo, clinical TZD therapy still relies on limited knowledge as to the early cascade of molecular and metabolic events that are the basis for antihyperglycaemic TZD action. A major difficulty in understanding the mechanisms of TZD action is to separate events that are causal for antidiabetic action from other humoral and metabolic phenomena that arise secondarily to glucose lowering or are unrelated to antidiabetic action. In this context, studies on the direct interaction of TZDs with isolated cells and tissues in vitro are important, because such an approach allows distinguishing the direct interaction of TZDs with a target tissue from events related to TZDinduced changes in ambient hormones and metabolites. This review summarizes available knowledge regarding metabolic TZD action on fat, muscle, and liver in vitro, and discusses to which extent in vitro studies have provided a basis for understanding the mechanisms of antidiabetic action in vivo.

\section{Adipose tissue}

Direct TZD action on isolated fat. The observation that in vitro, TZD compounds are specific and potent agonists of peroxisome proliferator-activated receptor- $\gamma$ (PPAR $\gamma)$ [23, 24] was a breakthrough in the search of molecular targets. PPAR $\gamma$ is a member of the nuclear hormone receptor family, it is abundantly expressed in adipose tissue [25, 26, 27], and forms heterodimers with retinoid $X$ receptor- $\alpha(\operatorname{RXR} \alpha)$ [28, 29]. Like other nuclear receptors, PPAR $\gamma$ is considered to act exclusively by modulating gene expression. Any binding of an agonistic ligand thus triggers structural reconformation of the PPAR $\gamma-\mathrm{RXR} \alpha$ heterodimer with the release of corepressors and the recruitment of coactivators $[30,31]$. The activated receptor-cofactor complex modulates transcription patterns due to interacting with peroxisome proliferator response elements (PPREs) located in the promotor regions of many genes, most of which are important for lipid metabolism [32].

The major physiologic role of PPAR $\gamma$ is its involvement in adipocyte differentiation. PPAR $\gamma$ is increasingly expressed during the early phase of the development of preadipocytes into mature fat cells and acts

together with CCAAT/enhancer binding proteins

$17,18]$ and fat $[5,6,8,19]$ ex vivo. In parallel to TZD-induced peripheral insulin sensitization, an im- with TZDs have persistent hyperglycaemia as long as sulin administration $[5,6]$. This implies that TZDs amplify the action of insulin on target tissues and tizers.

Euglycaemic-hyperinsulinaemic clamp tests on Type II diabetic patients and insulin resistant rodents showed that oral TZD treatment improves insulinstimulated glucose disappearance $[7,8,9,10,11,12$, $13,14,15]$, which is reflected by increased glucose transport into insulin-stimulated skeletal muscle $[16$, 
(C/EBPs) to stimulate full differentiation $[33,34]$. In vitro, the adipogenic activity of PPAR $\gamma$ is shown, for example, by the increased expression of PPAR $\gamma$ which stimulates cultured fibroblasts to develop into mature fat cells [35], and by the ectopic expression of PPAR $\gamma$ which together with $\mathrm{C} / \mathrm{EBP} \alpha$ can trigger myoblasts with no inherent adipogenic potential to transdifferentiate into adipocytes [36].

PPAR $\gamma$-agonistic potencies and efficacies of TZDs are routinely determined by means of reporter assays, which quantify in vitro the transcriptional rates of genes provided with PPREs (e.g. [37, 38, 39]). As functional PPAR $\gamma$ agonists, TZDs strongly induce the differentiation of many cell types into mature adipocytes in vitro [23, 40, 41, 42, 43, 44, 45, 46]. Of note, during the TZD-induced transition of a stem cell into a mature adipocyte, the cell increasingly acquires the ability to respond to insulin and progressively expresses genes important for glucose metabolism, like glucose transporters [40, 45, 47] or uncoupling proteins $[48,49,50]$. Whereas the induction of a set of genes required for insulin responsiveness and carbohydrate handling seem to be part of the normal adipogenic program, other attributes seem specific for fat cell differentiation under TZD exposure. Thus, TZDs favour the development of brown rather than white fat cells [48, 49], and specifically address preadipocytes from subcutaneous fat with little influence on preadipocytes obtained from an omental depot [41].

The role of PPAR $\gamma$ in adipocyte differentiation as well as the potential of TZDs to trigger differentiation of adipocytes via PPAR $\gamma$ has been established and summarized in a number of other reviews (e.g. [31, $32,51,52,53,54])$. It is less clear, however, in what way and to what extent PPAR $\gamma$-activation and direct interaction with fat cells are the initial events that ultimately lead to antidiabetic TZD action in vivo.

Adipogenic TZD action in vivo. An essential role of PPAR $\gamma$ for the development of adipocytes not only in vitro, but also under physiologic conditions in vivo, is implicated by PPAR $\gamma$ knock out mice in which white and brown adipose tissue can develop only from stem cells with at least one intact allele for PPAR $\gamma[55,56]$. Furthermore, adipogenic action of oral TZD treatment is indicated by increases in adiposity and body weight which accompany the therapeutic effects on glucose homeostasis [57, 58, 59]. Closer inspection shows, however, that TZDs do not simply induce growth of fat mass but trigger adipose tissue remodelling in a sophisticated manner. This is in line with the observation that TZD stimulation in vitro leads to the development of adipocytes with specific attributes. In rodents, TZDs stimulate the development of small adipocytes and the apoptosis of large adipocytes, which results in adipose tissue predominantly composed of small cells [57, 60, 61]. Furthermore, considerable growth of subcutaneous adipose mass without a

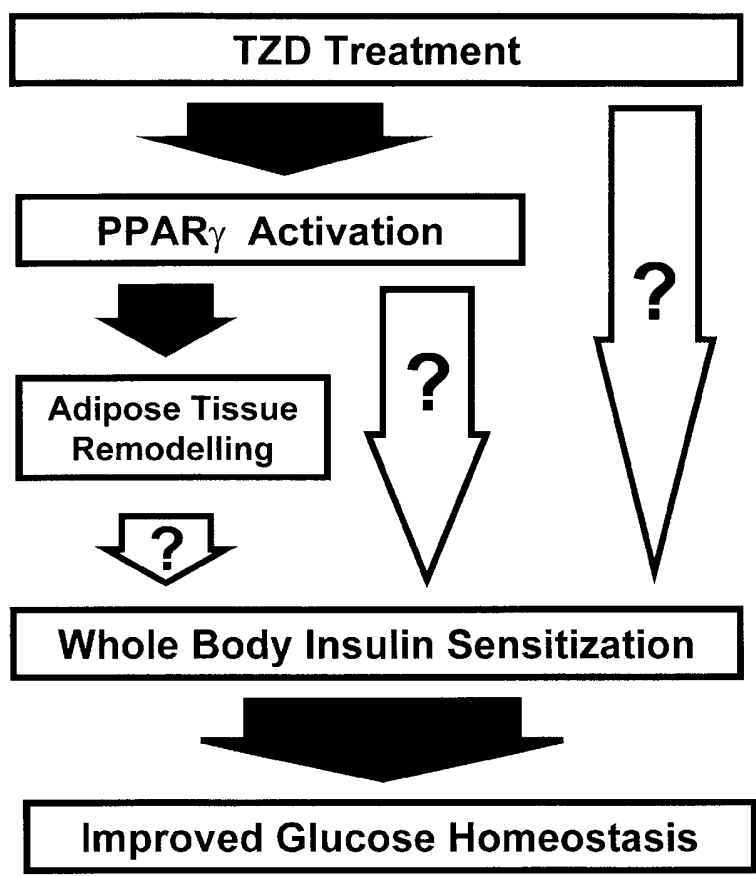

Fig. 2. Possible modes of antidiabetic TZD action. It is undisputed that TZDs trigger adipose tissue remodelling via PPAR $\gamma$ and that insulin sensitization is essential for antihyperglycaemic TZD action (full arrows). Several modes of action are under discussion for the causal chain of events leading to insulin sensitization (open arrows). Whether PPAR $\gamma$ activation and/or direct effects on adipose tissue are the sole cause of improvement of glucose homeostasis is not yet clear

change, or even with a decrease, in visceral fat is seen in humans treated with troglitazone $[62,63,64]$ which obviously reflects the superior effect of TZDs on subcutaneous versus omental adipocytes as shown in vitro [41].

Hence, evidence suggests that direct and PPAR $\gamma$ dependent effects on adipocytes documented in vitro are responsible for adipose tissue remodelling in vivo. How far the insulin sensitizing and antidiabetic activities of TZDs are secondary to stimulation of PPAR $\gamma$ and/or to adipose tissue remodelling, however, has yet to be established. Three modes of antidiabetic TZD action seem possible (Fig. 2): (i) whole body insulin sensitization is secondary to PPAR $\gamma$-mediated adipogenesis and adipose tissue remodelling; (ii) both adipogenesis and insulin sensitization are induced via PPAR $\gamma$, but different pathways are involved distal to receptor activation; and (iii) insulin sensitization, in contrast to adipogenesis, is mediated via a mechanism that does not involve PPAR $\gamma$. Although efforts to pinpoint to what extent each of these mechanisms is responsible for antidiabetic TZD action have not brought forth a final answer, it is worth while to critically analyse this question on the basis of presently available knowledge.

PPAR $\gamma$ and antidiabetic TZD action. Studies using PPAR $\gamma$-deficient mice could be very helpful in deter- 
mining, whether PPAR $\gamma$ activation as documented in vitro is essential for antidiabetic TZD action in vivo but unfortunately such animals are hardly viable [55, 65]. Although changes in insulin action characterizing heterozygous knock-out mice $\left(P P A R \gamma^{+/-}\right)$[65] and humans with mutations or polymorphisms in the PPAR $\gamma$ gene $[66,67]$ suggest PPAR $\gamma$-dependent regulation of glucose homeostasis in vivo, there is disagreement as to whether available data supports or challenges the hypothesis that increased PPAR $\gamma$ activity relates to higher insulin sensitivity $[22,68]$.

The most important observation supporting a causal interdependence between TZD-induced PPAR $\gamma$ activation and the improvement of glucose homeostasis is the association of PPAR $\gamma$ agonistic activity in vitro with antidiabetic action in vivo, which characterizes numerous TZDs [16, 37, 69, 70, 71, 72], and also non-TZD PPAR $\gamma$ agonists belonging to the classes of isoxazolidinediones $[73,74]$, tyrosine derivatives [75, $76,77]$, and phenylacetic or phenoxyacetic acid derivatives [37]. Although the maximal antihyperglycaemic potentials of many TZDs and other PPAR $\gamma$ agonists are similar, oral dose requirements for half-maximal glucose lowering in diabetic mice differ considerably and correlate strongly with PPAR $\gamma$ binding activities and transactivating potentials of the respective compound in vitro $[37,69,71]$. Furthermore, antidiabetic action has also been ascribed to agonistic ligands of $\mathrm{RXR} \alpha$, the heterodimeric partner of PPAR $\gamma[78,79]$. Against this background it is tempting to relate the glucoregulatory effects of both PPAR $\gamma$ and $R X R \alpha$ agonists to the stimulation of the PPAR $\gamma-R X R \alpha$ heterodimer and thus to the same molecular pathway.

All these reports on qualitative and quantitative correlations of receptor activation with improvement of glucose homeostasis led to a broad acceptance of the hypothesis that TZD-induced insulin sensitization and amelioration of hyperglycaemia are secondary to PPAR $\gamma$ activation. Other evidence suggests, however, that the mechanisms underlying metabolic TZD action could be more complex. The new TZDs RWJ241947 (MCC-555), NC-2100, and PAT5A, and also the antidiabetic oxadiazolidinedione YM440 (molecular structures in Fig. 1), carry antihyperglycaemic and insulin sensitizing potentials at least equal to those of established TZDs [38, 39, 80, 81, 82], although they have markedly lower efficacies for PPAR $\gamma$ affinity, PPAR $\gamma$ transactivation, and adipocyte differentiation in vitro [38, 39, 80, 81]. In addition, no increases in fat and body weight which characterize most TZDs [57, 58, 59] are found in response to treatment with NC-2100 or YM440 [38, 81], which suggests little adipogenic action in vitro and in vivo. Dissociation of adipogenic and metabolic TZD action has also been reported for isolated adipocytes transfected with a PPAR $\gamma$ dominant-negative mutant, in which TZDs and other agonists maintained their ability to stimulate glucose transport, albeit their adipogenic potential was severely impaired [83].
The failure of several TZDs to show PPAR $\gamma$ activation and adipogenic action proportionate to their glucose-lowering potentials implicates that increased PPAR $\gamma$ activity alone is not sufficient to explain both adipogenic and antidiabetic properties of all TZDs. Apart from the option that metabolic TZD action could in part rely on molecular targets other than PPAR $\gamma$, an alternative concept referred to as the selective PPAR modulator (SPPARM) model can explain different actions via the same receptor. Basically, the SPPARM model holds that the repertoire of target genes addressed via PPAR $\gamma$ depends on the individual ligand, a mode of action that is established for other nuclear receptors [84]. In vitro, structural reconfirmation and cofactor recruitment by PPAR $\gamma$ differ between TZD versus non-TZD ligands and also between individual TZD compounds $[85,86]$ suggesting that PPAR $\gamma$ is indeed capable of ligand-specific signalling. Adding to the complexity, PPREs located in the promotor regions of different genes are not entirely identical and availability of cofactors could be based on tissue-specific expression, which in turn could vary depending on the physiologic or pathophysiologic state (e.g. fasted vs fed, lean vs obese, healthy vs diabetic). Hence, the structure of receptor-ligand-cofactor-PPRE-complexes that arise to modulate gene transcription can depend on a number of factors including the specific PPAR $\gamma$ ligand, the tissue site, and the metabolic state.

Challenging traditional views about the agonistic or antagonistic character of a ligand, the SPPARM model could explain, how each individual TZD addresses a specific set of genes, elicits a unique pattern of gene transcription, and triggers a unique biologic response without requiring another primary target in addition to PPAR $\gamma$. This implies that a partial or context-dependent agonism of PPAR $\gamma$ could be sufficient for antidiabetic action as long as the ligand affects a specific and yet unidentified gene (or set of genes) responsible for insulin sensitization.

With respect to the hypothesis of PPAR $\gamma$ being the only relevant target of TZDs, the consequences of such hypothetical ligand-specific signalling are manifold. The SPPARM model invalidates the argument that an antidiabetic compound lacking major PPAR $\gamma$ activity in a reporter assay must act via an other molecular target. On the other hand, the model challenges the basic assumption that the potential of a given compound to trigger insulin sensitization and glucose lowering in vivo can be estimated from its PPAR $\gamma$ agonistic activity in vitro. The latter point questions the usefulness of PPAR $\gamma$ reporter assays in search for promising compounds and also weakens the argument that PPAR $\gamma$ agonism in vitro correlates with antidiabetic action in vivo $[37,69,71]$. Hence, the extent to which metabolic action of TZDs is caused by PPAR $\gamma$ signalling is difficult to assess and further research will be necessary to differentiate the contribution of 
this receptor and other targets to the antidiabetic action of TZD compounds.

Adipose tissue and antidiabetic TZD action. The causal relevance of PPAR $\gamma$-mediated effects on adipose tissue for antidiabetic TZD action can not be evaluated only by weighing the evidence for and against PPAR $\gamma$-dependency of glucose lowering but also by analysing if and in what way adipose tissue is essential. In this context, TZD-induced amelioration of hyperglycaemia in patients and mice with lipodystrophy (i.e. with a distinct shortage in adipose tissue mass) has been argued to indicate a mode of action that does not require direct interaction with fat [87, 88]. Opposing results from another lipodystrophic mouse model [89], however, give alternative interpretations such that TZD action could depend on an interaction with residual fat or that fatty livers, as characteristic of such syndromes, could functionally replace adipose mass. Thus so far, studies on TZD action in lipodystrophy failed to clarify whether adipose tissue is the primary site of the antidiabetic effects of TZDs [90].

Of note, the hypothesis stating that TZDs act exclusively via fat contrasts somewhat with the minor contribution that adipose tissue makes to whole body glucose metabolism [20, 21]. Actually, the predominant role in TZD-dependent glucose lowering is unanimously attributed to increased insulin-stimulated glucose disposal into skeletal muscle $[7,12,13,15,17$, $22]$ with many, but not all, reports suggesting a contribution of reduced hepatic glucose output ([7, 8, 9, 10, $11,15]$ vs $[12,13,14])$. To interpret antidiabetic TZD action as mediated by adipose tissue, it is therefore necessary to hypothesize a TZD-induced metabolic or humoral signal, which is released from fat and acts on skeletal muscle and probably on the liver (Fig. 3). Identification of this hypothetical TZD-induced messenger would be crucial to strengthen the contention of fat-dependent TZD action.

Prerequisites essential for such a putative messenger are (i) that its output from fat changes under TZD treatment and (ii) that it modulates glucose metabolism of skeletal muscle and perhaps the liver. At present, non-esterified fatty acids (NEFA) are regarded as the main candidate, because TZD treatment reduces plasma NEFA [5, 11, 71, 72, 82, 91, 92] and because NEFA are established modulators of insulin-stimulated glucose transport and glycogen synthesis in skeletal muscle in vitro and in vivo $[93,94,95,96]$. The causal sequence would be that adipogenic TZD action on fat supports triglyceride storage and, hence, the withdrawal of NEFA from the circulation which improves muscle insulin sensitivity and glucose homeostasis [97]. However, the simple association of decreased plasma NEFA with antidiabetic TZD action is not sufficient to confirm such hypothesized sequence of events. Actually, no evidence has yet been provided

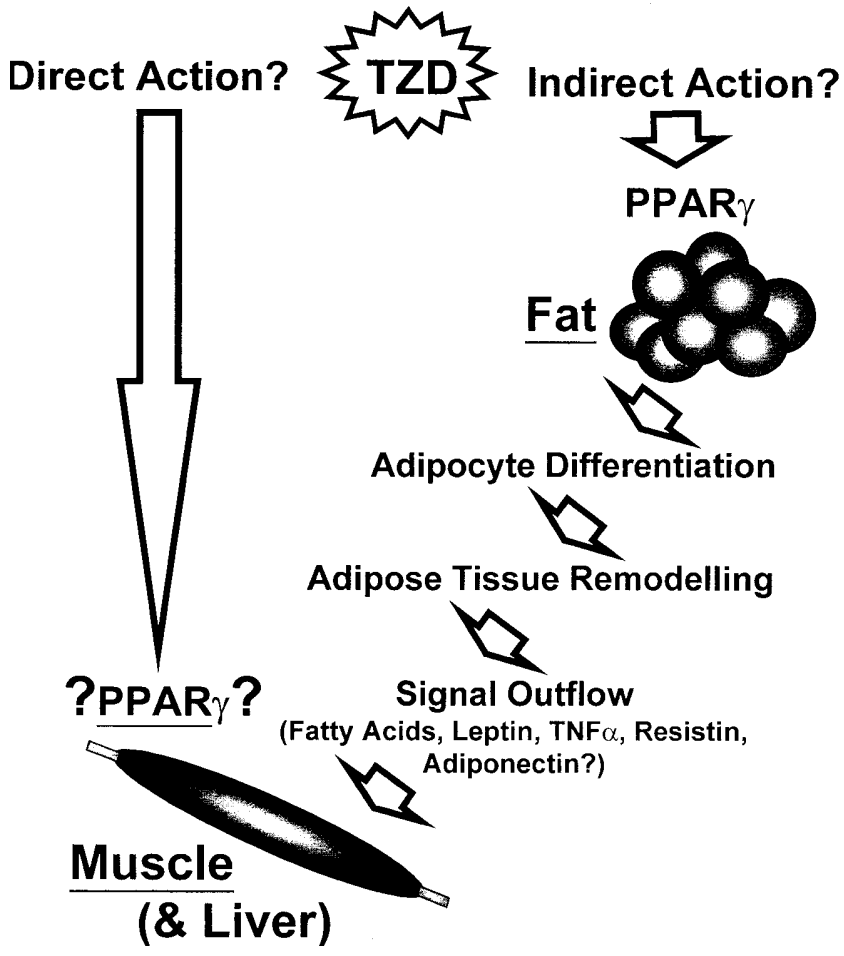

Fig. 3. Mode of TZD action on muscle and liver: two hypotheses. Amelioration of insulin resistance of skeletal muscle (and probably also of the liver) is an essential step in the cascade of events leading to antihyperglycaemic TZD action. At present, it is not known, to what extent TZDs address muscle and liver via a PPAR $\gamma$-induced messenger from the adipocyte and to what extent they act directly via PPAR $\gamma$ and/or other molecular targets

to confirm that the TZD-induced reduction in plasma NEFA precedes muscle insulin sensitization rather than being a secondary phenomenon.

Beside being a source of NEFA, adipose tissue is increasingly recognized as an endocrine organ that produces glucoregulatory hormones like leptin, tumour necrosis factor- $\alpha$ (TNF- $\alpha$ ), resistin, and adiponectin. Since TZDs modulate their adipose expression, these secretory peptides have also been referred to as candidates for TZD-induced fat-to-muscle signalling (Fig. 3) [58, 60, 98, 99, 100, 101, 102, 103]. Hard evidence, however, for a crucial role of fatderived peptides is scarce. Leptin can hardly be held responsible for antidiabetic TZD action, because the vast majority of animal experiments documenting antihyperglycaemic effects have used $o b / o b$ mice, $d b / d b$ mice, or $f a / f a$ rats, which are incapable of leptin signalling because of mutations in the genes encoding either for leptin or the leptin receptor [104, 105]. The ability of resistin to act on skeletal muscle and liver has not been evaluated yet, whereas TNF- $\alpha$ modulates insulin action in a cultured muscle cell line [106] but fails to influence glucose metabolism of native skeletal muscle specimens in vitro $[107,108]$. The most plausible peptide candidate seems to be adiponectin, which is increasingly produced under TZD treatment 
[98, 99], exhibits glucose-lowering activity [98, 109, 110], and modulates fuel metabolism of hepatocytes as well as of native and cultured muscle in vitro [109, 110]. Nevertheless, it remains to be shown that adponectin is essential for the metabolic action of TZDs.

Conclusion, adipose tissue. TZDs thus have a major direct impact on isolated adipocytes in vitro, which is attributable to PPAR $\gamma$-mediated modulation of gene transcription leading to cellular differentiation. The mechanisms characterized in vitro are obviously responsible for structural and functional changes in adipose tissue during oral TZD administration in vivo. It is not clear, however, to what extent these direct effects on fat also cause TZD-induced improvement of glucose homeostasis, which is mainly a function of skeletal muscle. To understand whether TZD actions on muscle and liver are secondary to signal output from adipose tissue, it needs to be clarified, if changes in circulating NEFA are the cause or the result of insulin sensitizing TZD action and if fat-derived peptides have the potential to act as TZD-induced messengers to skeletal muscle and liver.

\section{Skeletal muscle}

Direct TZD action on isolated muscle. Although indirect action of TZDs via a fat-derived mediator is a plausible concept, antidiabetic action could, alternatively or additionally, also relate to direct interaction with skeletal muscle (Fig. 3). Direct action on muscle could explain why the antidiabetic efficacy of an individual TZD does not necessarily correlate with its adipogenic and antihyperlipidaemic potentials $[38,39$, 89]. Aiming to differentiate direct from indirect effects, the examination of TZD action on isolated skeletal muscle in vitro, and hence in the absence of any signal from other tissues, is an important experimental approach.

In many studies, TZDs were found to stimulate glucose transport into skeletal muscle in vitro [16, 70, $111,112,113,114,115,116,117,118,119,120]$ but the accompanying changes in intracellular glucose fluxes were rather inconsistent, ranging from stimulation to inhibition of both glucose oxidation and glycogen synthesis $[16,70,111,112,113,114,121]$. The heterogeneity of effects on intracellular glucose routing is obviously related to the diversity in experimental settings. Studies varied with regard to the structure and concentration of the TZD used, the period of exposure, and the muscle preparations which included perfused rat hindlimb [120], freshly isolated rat soleus muscle [16, 111, 112, 113, 121], pre-cultured human muscle biopsies $[114,115,116]$, and permanently cultured muscle cell lines [70, 117, 118, 119]. Comparing different studies is further complicated by the lipophilic character of TZDs that strongly bind to protein [122], which implies a modulation of the bioavailable
TZD concentration in vitro by the quantity and quality of protein and detergent added to the incubation or perfusion medium. In spite of such differences in the applied experimental protocols, cautious analysis of available information leads to interesting conclusions.

TZD-induced glucose transport in vitro has been reported to be independent of concomitant insulin stimulation $[16,111,112,114,115,116,117,118$, 119] and to occur very rapidly within 30 to $90 \mathrm{~min}$ not only in skeletal muscle [16, 111, 112, 113, 115, 120], but also in cardiomyocytes [123] and adipocytes [124]. This led some authors to attribute an acute "insulin-mimetic" potential to TZDs $[115,124]$ but such interpretation needs to be applied with caution. Whereas insulin is a storage signal directing intracellular glucose flux mainly into glycogen [111, 125], glucose transport into short-term TZD-exposed muscle increases in association with a very marked increase of the glycolytic flux and the depletion of glycogen $[16,111,112,113,120]$. Thus insulin-mediated glucose uptake relates to transport and glycogen synthesis, which should not be mistaken for glucose transport without concomitant glycogen storage. The substrate handling of muscle acutely exposed to TZDs in vitro resembles the metabolic response to contractions or to anoxia $[125,126]$ rather than the metabolic response to insulin.

Although acute stimulation of total glycolysis in isolated muscle is seen over a broad range of TZD concentrations, distinction of aerobic versus anaerobic glucose utilization suggests that different mechanisms are involved at low versus high concentrations. Whereas low TZD concentrations inhibit the conversion of glucose into $\mathrm{CO}_{2}$ (Fig. 4A) [112, 113], concentrations above those prevailing in the circulation of treated patients trigger very distinct increases in both aerobic and anaerobic fuel catabolism (Fig. 4B) [16, 112]. A catabolic effect on glucose metabolism as induced by high TZD concentrations (Fig. 4B) is likewise triggered by very high concentrations of other compounds $[125,127]$ and therefore could represent a rather unspecific response to stress. These considerations emphasize how misleading it can be to attribute an insulin-mimetic potential to TZDs without any evidence, apart from the acute stimulation of glucose transport.

A specific mechanism probably underlies the acute effect of low micromolar TZD concentrations on muscle glucose handling, which can be described as a TZD-induced shift of glycolytic flux from the aerobic towards the anaerobic pathway (Fig. 4A) [112, 113]. Under these conditions, $\mathrm{CO}_{2}$ production from both glucose and NEFA is markedly reduced and is accompanied by a distinct increase in lactate production, whereby increased glucose uptake and glycogen depletion obviously compensate for the lower yield of ATP from anaerobic than aerobic substrate utilization (Fig. 4A) [112, 113]. Such changes in muscle glucose 

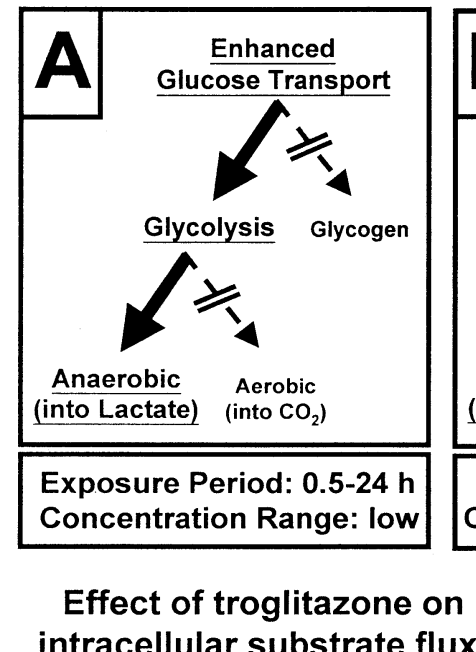
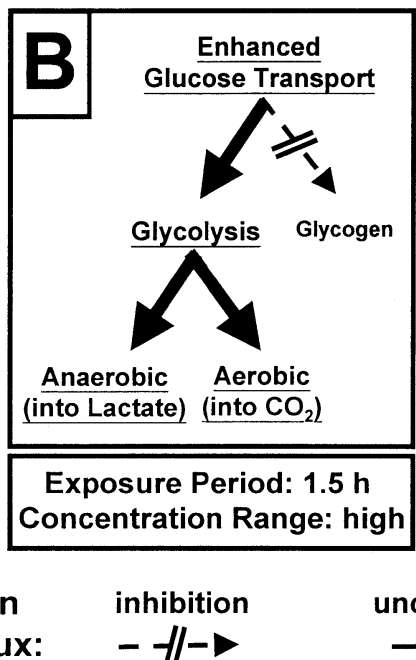
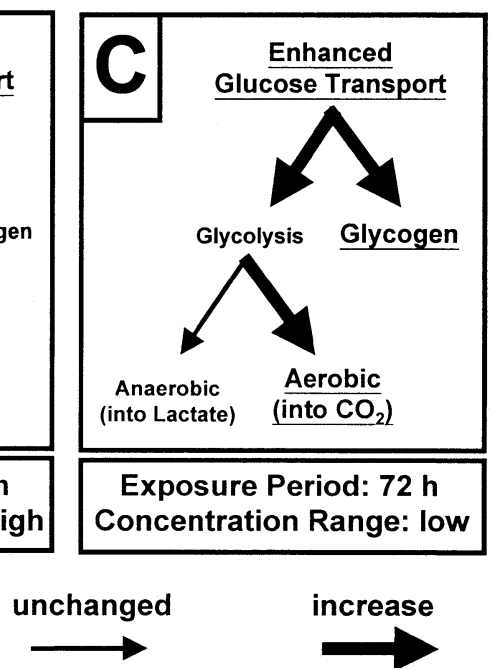

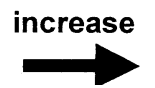

Fig. 4A-C. Troglitazone action on isolated rat soleus muscle. Depending on the concentration and exposure period, troglitazone stimulates glucose transport into the isolated rat soleus muscle in association with divergent effects on intracellular glucose routing. A Short-term exposure to troglitazone concentrations in the low micromolar range inhibits glucose oxidation and shifts glycolytic flux into lactate production which, presumably due to higher substrate demands for anaerobic ATP production, is associated with glycogen depletion ("anoxialike" response); B short-term exposure to troglitazone concentrations in the high micromolar range triggers aerobic and anaerobic glycolysis, and glycogen depletion, which might be an unspecific stress response ("contraction-like" response); and $\mathbf{C}$ long-term exposure to troglitazone concentrations in the low micromolar range increases insulin-stimulated glycogen storage and glucose oxidation ("insulin-like" or "insulin-sensitizing" response). Adapted from references [111, 112, 113, 121]

handling are in line with inhibitory action of TZDs on mitochondrial respiration, a mechanism which is believed to contribute to the action of the antidiabetic agent metformin [128, 129].

Evidence for direct and acute TZD action on the mitochondrium in vivo, however, is scarce. Although a troglitazone-induced increase of insulin-stimulated glucose disposal within $20 \mathrm{~min}$ and amelioration of hyperglycaemia within $2.5 \mathrm{~h}$ have been reported in rodents $[5,130]$, studies on humans point to a delayed action on glucose homeostasis. However, such delay in antidiabetic action does not exclude the involvement of an acute mitochondrial mechanism, because short-term stimulation of glycolysis by regular bouts of exercise will, in the long-term, also result in insulin sensitization.

In contrast to glycogen depletion by short-term TZD exposure of freshly isolated muscle specimens, long-term TZD exposure increases glycogen synthase activity and glycogen synthesis in muscle-derived cell cultures $[114,115,116,131]$. In agreement with these findings from cell cultures, the acute glycogenolytic effect of troglitazone on isolated rat soleus muscle turns into a glycogenic response after a prolonged exposure for $72 \mathrm{~h}$ (Fig. 4C) [121]. Under the latter conditions, an insulin-dependent increase in glycogen synthesis is accompanied by an insulin-independent increase in glucose oxidation [121], which is a pattern of changes as in soleus muscle specimens prepared from orally TZD-treated obese rodents [16, 18, 91]. Although parallel responses to prolonged TZD treatment in vitro and in vivo support the idea that direct action on muscle could be important for therapeutic TZD action, any conclusion from long-term incubation of isolated muscle is hampered by the fact that the regulation of glucose metabolism could change considerably in muscle cells devoid of their physiologic environment. Therefore, it is important to be cautious when extrapolating findings from long-term incubated or cultured muscle to the physiologic situation.

Molecular targets of TZDs in skeletal muscle. Whereas the undisputed mediator of a large number of TZD effects on adipocytes is PPAR $\gamma$, an involvement of this receptor in the direct actions on skeletal muscle is not established. In muscle, mRNA encoding for PPAR $\gamma$ is much lower than in fat $[25,26,27]$ but PPAR $\gamma$ protein has been described to be relatively more abundant, reaching 31 to $100 \%$ of adipose concentrations [132]. However, not a single response of skeletal muscle could yet be clearly attributed to PPAR $\gamma$ activation and the functional relevance of PPAR $\gamma$-signalling is still not clear in this tissue.

In contrast to the lack of evidence for PPAR $\gamma$ signalling there is evidence for PPAR $\gamma$-independent actions of TZDs on skeletal muscle which are obviously responsible for the acute inhibition of mitochondrial fuel oxidation in isolated muscle specimens [113]. PPAR $\gamma$-mediated actions depend on rather slow processes, including gene expression and protein synthesis. However, TZDs diminish muscular $\mathrm{CO}_{2}$ production in vitro within $30 \mathrm{~min}$, which can not be inhibited by blockers of transcription or translation [113]. 
Conclusion, skeletal muscle. In addition to their influence on isolated adipocytes, TZDs directly and PPAR $\gamma$-independently affect glucose metabolism of isolated skeletal muscle in vitro, which includes insulin-independent stimulation of glycolysis and, at low concentrations, inhibition of mitochondrial $\mathrm{CO}_{2}$ production. While major progress has been made in understanding PPAR $\gamma$-mediated gene expression, adipose tissue remodelling, and signal output from fat, the relevance of the direct TZD action on skeletal muscle for the therapeutic effects of TZD administration is still not clear. To fully understand the mode of antidiabetic TZD action, it will be essential to differentiate the contribution of PPAR $\gamma$-dependent versus PPAR $\gamma$-independent mechanisms, and of direct versus indirect actions on skeletal muscle.

\section{Liver}

Direct TZD action on isolated liver. Increased glucose disposal into skeletal muscle is very important for TZD-induced glucose lowering but, although not confirmed in all studies [12, 13, 14], a contribution of reduced hepatic glucose output seems very likely $[7,8$, $9,10,11,15]$. As for muscle, TZD action on the liver might be due to direct effects as well as to indirect actions via fat-derived messengers (Fig. 3).

In perfused rat livers as well as in isolated hepatocytes, TZDs were reported to acutely reduce the rate of glucose release, which was mainly a function of reduced gluconeogenesis from lactate in most settings [133, 134, 135, 136, 137]. Like TZD-induced glucose transport into isolated muscle, acute suppression of hepatic glucose output in vitro did not depend on concomitant insulin stimulation, and was therefore interpreted as "insulin-mimetic" TZD action [133, 134, 135]. At variance to what should be expected for full insulin-mimetic action, the reduction of glucose production by TZDs was associated with a considerable stimulation of the glycolytic pathway and with an increased net lactate release [135, 136, 138]. Although the rates of glycogen synthesis and glucose oxidation were not determined in liver, acute effects on the isolated liver seem to resemble those seen in isolated skeletal muscle. In both tissues, TZDs shift substrate flux into glycolysis and, hence, away from alternative routes like glucose production and glycogen synthesis.

At variance to the glycolytic effect of short-term TZD exposure, long-term exposure increased glycogen synthase activity in cultured hepatocytes [131, 139] which correlates with findings on long-term TZD-exposed cultured muscle $[115,116]$. Whether increased activity of this enzyme is accompanied by increased glycogen storage in TZD-treated liver cells, however, can not be known without appropriate data on substrate fluxes and glycogen content.
Molecular targets for TZDs in liver. The healthy liver resembles skeletal muscle in that it hardly expresses PPAR $\gamma[25,26]$ and in that a regulatory role of PPAR $\gamma$ has not yet been clearly shown. In isolated muscle, rapid TZD stimulation of glycolysis does not seem to depend on PPAR $\gamma$ signalling [113] and a comparable glycolytic effect on isolated liver as well as data on troglitazone-induced inhibition of phosphoenolpyruvate carboxykinase gene expression [140] suggest that TZDs address hepatocytes, like muscle cells, via PPAR $\gamma$-independent pathways.

Whereas PPAR $\gamma$-independent mechanisms seem to account for the acute metabolic actions of TZD compounds, the development of hepatic steatosis could render the liver responsive for PPAR $\gamma$-mediated adipogenic TZD action [90, 141, 142, 143]. Steatotic hepatocytes resemble adipocytes not only with respect to triglyceride accumulation, but also in that they abundantly express PPAR $\gamma$ and several other genes which characterize fat cells $[90,141,142]$. Increased abundance of PPAR $\gamma$ in fatty livers could explain, why TZDs fail to induce lipid accumulation in livers of healthy animals, but exacerbate pre-existing steatosis and the expression of adipocyte-specific genes in livers of lipoatrophic and obese mice [90, 141, 143]. Nevertheless, worsening of lipid accumulation, which could be indicative of hepatic PPAR $\gamma$-signalling, has only been described in mouse liver, whereas TZDs were reported to ameliorate hepatosteatosis in rats and humans [64, 72, 144, 145].

Nuclear receptors other than PPAR $\gamma$ could also be hepatic targets for at least some TZDs. In vitro, the TZDs KRP-297 and pioglitazone, as well as the isoxazolidinedione JTT-501 (Fig. 1) transactivate both PPAR $\gamma$ and PPAR $\alpha$ [72, 73, 146]. PPAR $\alpha$ is mainly expressed in the liver and is regarded as the mediator of the antihyperlipidaemic action of fibrates [147]. As pure PPAR $\alpha$ agonists can elicit insulin-sensitization [7, 148, 149, 150], this receptor could contribute jointly with PPAR $\gamma$ to the antidiabetic action of dual agonists. Of note, activation of both subtypes might even be preferable to pure PPAR $\gamma$-agonism, because PPAR $\alpha$ activity could increase the antihyperlipidaemic efficacy of a TZD $[72,151]$ and could attenuate PPAR $\gamma$-induced adiposity and weight gain [150].

In vitro, the TZD troglitazone also transactivates human pregnane $\mathrm{X}$ receptor (PXR) at concentrations required for the stimulation of PPAR $\gamma$ [152]. The potential of this hepatic nuclear receptor to mediate antidiabetic action is not clear but PXR activation by troglitazone has been suggested to contribute to the improvement of glucose homeostasis in dexamethasone-treated rats [153].

Conclusion, liver. The liver resembles skeletal muscle in that acute TZD exposure in vitro leads to an insulinindependent increase in glycolysis, and in that there is a lack of any evidence for functional PPAR $\gamma$ signalling (except for severely steatotic livers of specific mouse 
models). At variance to muscle, however, nuclear receptors other than PPAR $\gamma$ are expressed in the liver which provide targets for at least some TZDs in vitro, and therefore could contribute to their metabolic effects in vivo. Thus, TZDs are basically capable to directly modulate hepatic glucose metabolism in vitro, but the precise contribution of direct effects on the liver to antidiabetic TZD action in vivo is not yet clear.

\section{Concluding remarks}

Major progress has been made in understanding the mechanisms that causally underlie the metabolic actions of TZD compounds. Antihyperglycaemic action of TZDs is predominantly based on the amelioration of insulin resistance, with skeletal muscle as the quantitatively most important tissue for insulin-induced glucose lowering. In vitro, TZDs activate PPAR $\gamma$ and stimulate adipocyte differentiation, which provides the mechanism for TZD-induced adipose tissue remodelling in vivo and seems to be associated with the output of adipose-derived signals that might modulate glucose metabolism of other tissues.

Beyond these established findings, however, we are still not able to fully understand the causal chain leading to metabolic TZD action. Direct and PPAR $\gamma$-independent effects on glucose metabolism of isolated skeletal muscle and liver suggest that the involvement of other molecular mechanisms, in addition to PPAR $\gamma$-activation in adipose tissue, can not be excluded. To further elucidate the mechanisms of antidiabetic TZD action, it will be necessary to sort out, if the predominant role presently ascribed to PPAR $\gamma$ activation in fat tissue holds true, or if we are biased by the overwhelming amount of research focusing on this receptor. Therefore, it will be important to establish the interdependence of adipogenic and antidiabetic TZD action and to elucidate the relative share of direct and indirect TZD actions on skeletal muscle, liver, and adipose tissue.

Sources. This review is based on scientific literature extracted from "Current Contents" (ISI, Thomson Scientific, Philadelphia, Pa., USA); January 1988October 2001.

Acknowledgements. Research on TZDs done at the authors' laboratory was supported by grants from the Austrian Science Fund (FWF, grants No. P11403-MED, P10416-MED, and P13049MED), by Sankyo (Tokyo, Japan), Boehringer Mannheim/ LaRoche (Mannheim, Germany), and Johnson and Johnson (Raritan, NJ, USA). The authors are grateful to B. Brunmair, F. Gras, S. Neschen, M. Roden, P. Nowotny and many other staff colleagues who contributed to this research.

\section{References}

1. Watkins PB, Withcomb RW (1997) Hepatic dysfunction associated with troglitazone. N Engl J Med 338: 916-917
2. Kohlroser J, Mathei J, Reichheld J, Banner BF, Bonkovsky HL (2000) Hepatotoxicity due to troglitazone: report of two cases and review of adverse events reported to the United States Food and Drug Administration. Am J Gastroenterol 95: 272-276

3. Gillies PS, Dunn CJ (2000) Pioglitazone. Drugs 60: 333-343

4. Lenhard MJ, Funk WB (2001) Failure to develop hepatic injury from rosiglitazone in a patient with a history of troglitazone-induced hepatitis. Diabetes Care 24: 168-169

5. Fujiwara T, Yoshioka S, Yoshioka T, Ushiyama I, Horikoshi H (1988) Characterization of new oral antidiabetic agent CS-045. Studies in $K K$ and $o b / o b$ mice and Zucker fatty rats. Diabetes 37: 1549-1558

6. Hofmann C, Lorenz K, Colca JR (1991) Glucose transport deficiency in diabetic animals is corrected by treatment with the oral antihyperglycemic agent pioglitazone. Endocrinology 129: 1915-1925

7. Ye J-M, Doyle PJ, Iglesias MA, Watson DG, Cooney GJ, Kraegen EW (2001) Peroxisome-proliferator-activated receptor (PPAR)- $\alpha$ activation lowers muscle lipids and improves insulin sensitivity in high fat-fed rats. Diabetes 50: 411-417

8. Oakes ND, Kennedy CJ, Jenkins AB, Laybutt DR, Chisholm DJ, Kraegen EW (1994) A new antidiabetic agent, BRL 49653, reduces lipid availability and improves insulin action and glucoregulation in the rat. Diabetes 43: 1203-1210

9. Lee M-K, Miles DG, Khourshed M, Gao K-M, Moossa AR, Olefsky JM (1994) Metabolic effects of troglitazone on fructose-induced insulin resistance in the rat. Diabetes 43: 1435-1439

10. Suter SL, Nolan JJ, Wallace P, Gumbiner B, Olefsky JM (1992) Metabolic effects of new oral hypoglycemic agent CS-045 in NIDDM subjects. Diabetes Care 15: 193-203

11. Bowen L, Stein PP, Stevenson R, Shulman GI (1991) The effect of CP 86,722, a thiozolidinedione derivative, on insulin sensitivity in lean and obese Zucker rats. Metabolism 40: 1025-1030

12. Inzucchi SE, Maggs DG, Spollett GR et al. (1998) Efficacy and metabolic effects of metformin and troglitazone in type II diabetes mellitus. N Engl J Med 338: 867-872

13. Kraegen EW, James DE, Jenkins AB, Chisholm DJ, Storlien LH (1989) A potent effect of ciglitazone on muscle insulin resistance induced by high fat feeding of rats. Metabolism 38: 1089-1093

14. Nolan JJ, Ludvik B, Beerdsen P, Joyce M, Olefsky J (1994) Improvement in glucose tolerance and insulin resistance in obese subjects treated with troglitazone. N Engl J Med 331: 1188-1193

15. Maggs DG, Buchanan TA, Burant CF et al. (1998) Metabolic effects of troglitazone monotherapy in type 2 diabetes mellitus. A randomized, double-blind, placebo-controlled trial. Ann Intern Med 128: 176-185

16. Fürnsinn C, Brunmair B, Meyer M et al. (1999) Chronic and acute effects of thiazolidinediones BM13.1258 and BM15.2054 on rat skeletal muscle glucose metabolism. Br J Pharmacol 128: 1141-1148

17. Zierath JR, Ryder JW, Doebber T et al. (1998) Role of skeletal muscle in thiazolidinedione insulin sensitizer (PPAR $\gamma$ agonist) action. Endocrinology 139: 5034-5041

18. Sreenan S, Keck S, Fuller T, Cockburn B, Burant CF (1999) Effects of troglitazone on substrate storage and utilization in insulin-resistant rats. Am J Physiol 276: E1119-E1129

19. Kanoh Y, Bandyopadhyay G, Sajan MP, Standaert ML, Farese RV (2000) Thiazolidinedione treatment enhances insulin effects on protein kinase C-/ activation and glucose transport in adipocytes of nondiabetic and Goto-Kakizaki type II diabetic rats. J Biol Chem 275: 16690-16696 
20. Baron AD, Brechtel G, Wallace P, Edelman SV (1988) Rates and tissue sites of non-insulin and insulin-mediated glucose uptake in humans. Am J Physiol 255: E769E774

21. DeFronzo RA (1988) The triumvirate: beta cell, muscle, liver. A collusion responsible for NIDDM. Diabetes 37: 667-687

22. Olefsky JM (2000) Treatment of insulin resistance with peroxisome proliferator-activated receptor $\gamma$ agonists. J Clin Invest 106: 467-472

23. Lehmann JM, Moore LB, Smith-Oliver TA, Wilkinson WO, Willson TM, Kliewer SA (1991) An antidiabetic thiazolidinedione is a high affinity ligand for peroxisome proliferator-activated receptor $\gamma$ (PPAR $\gamma)$. J Biol Chem 270: 12953-12956

24. Ibrahimi A, Teboul L, Gaillard D et al. (1994) Evidence for a common mechanism of action for fatty acids and thiazolidinedione antidiabetic agents on gene expression in preadipose cells. Mol Pharmacol 46: 1070-1076

25. Auboeuf D, Rieusset J, Fajas L et al. (1997) Tissue distribution and quantification of the expression of mRNAs of peroxisome proliferator-activated receptors and liver $\mathrm{X}$ receptor- $\alpha$ in humans. No alteration in adipose tissue of obese and NIDDM patients. Diabetes 46: 1319-1327

26. Tontonoz P, Hu E, Graves RA, Budavari AI, Spiegelman BM (1994) mPPAR $\gamma 2$ : tissue-specific regulator of an adipocyte enhancer. Genes Dev 8: 1224-1234

27. Fajas L, Auboeuf D, Raspe E et al. (1997) The organization, promotor analysis, and expression of the human PPAR $\gamma$ gene. J Biol Chem 272: 18779-18789

28. Kliewer SA, Umesono K, Noonan DJ, Heyman RA, Evans RM (1992) Convergence of 9-cis retinoic acid and peroxisome proliferator signalling pathways through heterodimer formation of their receptors. Nature 358: 771774

29. Tontonoz P, Graves RA, Budavari AI et al. (1994) Adipocyte-specific transcription factor ARF6 is a heterodimeric complex of two nuclear hormone receptors, PPAR $\gamma$ and RXR $\alpha$. Nucleic Acids Res 22: 5628-5634

30. Nolte RT, Wisley GB, Westin S et al. (1998) Ligand binding and co-activator assembly of the peroxisome proliferator-activated receptor- $\gamma$. Nature 395: 137-143

31. Horwitz KB, Jackson TA, Bain DL, Richer JK, Takimoto GS, Tung L (1996) Nuclear receptor coactivators and corepressors. Mol Endocrinol 10: 1167-1177

32. Schoonjans K, Staels B, Auwerx J (1996) Role of the peroxisome proliferator-activated receptors (PPAR) in mediating the effects of fibrates and fatty acids on gene expression. J Lipid Res 37: 907-925

33. Tontonoz P, Hu E, Spiegelman BM (1995) Regulation of adipocyte gene expression and differentiation by peroxisome proliferator activated receptor $\gamma$. Curr Opin Genet Dev 5: 571-576

34. Lowell BB (1999) PPAR $\gamma$ : An essential regulator of adipogenesis and modulator of fat cell function. Cell 99: 239-242

35. Tontonoz P, Hu E, Spiegelman BM (1994) Stimulation of adipogenesis in fibroblasts by PPAR $\gamma 2$, a lipid-activated transcription factor. Cell 79: 1147-1156

36. Hu E, Tontonoz P, Spiegelman BM (1995) Transdifferentiation of myoblasts by the adipogenic transcription factors PPAR $\gamma$ and C/EBP. Proc Natl Acad Sci USA 92: 98569860

37. Berger J, Leibowitz MD, Doebber TW et al. (1999) Novel peroxisome proliferator-activated receptor (PPAR) $\gamma$ and PPAR $\delta$ ligands produce distinct biological effects. J Biol Chem 274: 6718-6725
38. Fukui Y, Masui S, Osada S, Umesono K, Motojima K (2000) A new thiazolidinedione, NC-2100, which is a weak PPAR- $\gamma$ activator, exhibits potent antidiabetic effects and induces uncoupling protein 1 in white adipose tissue of KKAy obese mice. Diabetes 49: 759-767

39. Reginato MJ, Bailey ST, Krakow SL et al. (1998) A potent antidiabetic thiazolidinedione with unique peroxisome proliferator-activated receptor $\gamma$-activating properties. J Biol Chem 273: 32679-32684

40. Tafuri SR (1996) Troglitazone enhances differentiation, basal glucose uptake, and Glut1 protein levels in 3T3-L1 adipocytes. Endocrinology 137: 4706-4712

41. Adams M, Montague CT, Prins JB et al. (1997) Activators of peroxisome proliferator-activated receptor $\gamma$ have depotspecific effects on human preadipocyte differentiation. J Clin Invest 100: 3149-3153

42. Sottile V, Seuwen K (2000) Bone morphogenic protein-2 stimulates adipogenic differentiation of mesenchymal precursor cells in synergy with BRL 49653 (rosiglitazone). FEBS Lett 475: 201-204

43. Forman BM, Tontonoz P, Chen J, Brun RP, Spiegelman BM, Evans RM (1995) 15-deoxy-D 12,14-prostaglandin $\mathrm{J}_{2}$ is a ligand for the adipocyte determination factor PPAR $\gamma$. Cell 83: 803-812

44. Teboul L, Gaillard D, Staccini L, Inadera H, Amri E-Z, Grimaldi PA (1995) Thiazolidinediones and fatty acids convert myogenic cells into adipose-like cells. J Biol Chem 270: 28183-28187

45. Sandouk T, Reda D, Hofmann C (1993) Antidiabetic agent pioglitazone enhances adipocyte differentiation of 3T3F442A cells. Am J Physiol 264: C1600-C1608

46. Gimble JM, Robinson CE, Wu X et al. (1996) Peroxisome proliferator-activated receptor- $\gamma$ activation by thiazolidinediones induces adipogenesis in bone marrow stromal cells. Mol Pharmacol 50: 1087-1094

47. Wu Z, Xie Y, Morrison RF, Bucher NL, Farmer SR (1998) PPAR $\gamma$ induces the insulin-dependent glucose transporter GLUT4 in the absence of $\mathrm{C} / \mathrm{EBP} \alpha$ during the conversion of 3T3 fibroblasts into adipocytes. J Clin Invest 101: 2232

48. Digby JE, Montague CT, Sewter CP et al. (1998) Thiazolidinedione exposure increases the expression of uncoupling protein 1 in cultured human preadipocytes. Diabetes 47: 138-141

49. Paulik MA, Lenhard JM (1997) Thiazolidinediones inhibit alkaline phosphatase activity while increasing expression of uncoupling protein, deiodinase, and increasing mitochondrial mass in C3H10T1/2 cells. Cell Tissue Res 290: 79-87

50. Strobel A, Siquier K, Zilberfarb V, Strosberg AD, Issad T (1999) Effect of thiazolidinediones on expression of UCP2 and adipocyte markers in human PAZ6 adipocytes. Diabetologia 42: 527-533

51. Schoonjans K, Staels B, Auwerx J (1996) The peroxisome proliferator activated receptors (PPARs) and their effects on lipid metabolism and adipocyte differentiation. Biochim Biophys Acta 1302: 93-109

52. Rosen ED, Spiegelman BM (2001) PPAR $\gamma$ : a nuclear regulator of metabolism, differentiation, and cell growth. J Biol Chem 276: 37731-37734

53. Spiegelman BM (1998) PPAR- $\gamma$ : adipogenic regulator and thiazolidinedione receptor. Diabetes 47: 507-514

54. Auwerx J (1999) PPAR $\gamma$, the ultimate thrifty gene. Diabetologia 42: 1033-1049

55. Barak Y, Nelson MC, Ong ES et al. (1999) PPAR $\gamma$ is required for placental, cardiac, and adipose tissue development. Mol Cell 4: 585-595 
56. Rosen ED, Sarraf P, Troy AE et al. (1999) PPAR $\gamma$ is required for the differentiation of adipose tissue in vivo and in vitro. Mol Cell 4: 611-617

57. Hallakou S, Doaré L, Foufelle F et al. (1997) Pioglitazone induces in vivo adipocyte differentiation in the obese Zucker fa/fa rat. Diabetes 46: 1393-1399

58. De Vos P, Lefebvre AM, Miller SG et al. (1996) Thiazolidinediones repress $o b$ gene expression in rodents via activation of peroxisome proliferator-activated receptor $\gamma$. J Clin Invest 98: 1004-1009

59. Schwartz S, Raskin P, Fonseca V, Graveline JF, for the troglitazone and exogenous insulin study group (1998) Effect of troglitazone in insulin-treated patients with type II diabetes mellitus. N Engl J Med 338: 861-866

60. Okuno A, Tamemoto H, Tobe K et al. (1998) Troglitazone increases the number of small adipocytes without the change of white adipose tissue mass in obese Zucker rats. J Clin Invest 101: 1354-1361

61. Breider MA, Gough AW, Haskins JR, Sobocinski G, Iglesia FA de la (1999) Troglitazone-induced heart and adipose tissue cell proliferation in mice. Toxicol Pathol 27: 545-552

62. Akazawa S, Kawasaki E, Sun F, Eguchi K, Ito M (2000) Efficacy of troglitazone on body fat distribution in type 2 diabetes. Diabetes Care 23: 1067-1071

63. Mori Y, Yokoyama J, Murakawa Y et al. (1999) Effect of troglitazone on body fat distribution in type 2 diabetic patients. Diabetes Care 22: 908-912

64. Katoh S, Hata S, Matsushima M et al. (2001) Troglitazone prevents the rise in visceral adiposity and improves fatty liver associated with sulfonylurea therapy - a randomized controlled trial. Metabolism 50: 414-417

65. Kubota N, Terauchi Y, Miki H et al. (1999) PPAR $\gamma$ mediates high-fat diet-induced adipocyte hypertrophy and insulin resistance. Mol Cell 4: 597-609

66. Deeb SS, Fajas L, Nemoto M et al. (1998) A Pro12Ala substitution in PPAR $\gamma 2$ associated with decreased receptor activity, lower body mass index and improved insulin sensitivity. Nat Genet 20: 284-287

67. Barroso I, Gurnell M, Crowley VEF et al. (1999) Dominant negative mutations in human PPAR $\gamma$ associated with severe insulin resistance, diabetes mellitus and hypertension. Nature 402: 880-883

68. Bar-Tana J (2001) Peroxisome-proliferator-activated receptor gamma (PPAR $\gamma$ ) activation and its consequences in humans. Toxicol Lett 120: 9-19

69. Berger J, Bailey P, Biswas C et al. (1996) Thiazolidinediones produce a conformational change in peroxisomal proliferatoractivated receptor- $\gamma$ : binding and activation correlate with antidiabetic actions in db/db mice. Endocrinology 137: 4189-4195

70. Arakawa K, Ishihara T, Aoto M, Inamusa M, Saito A, Ikezawa K (1998) Actions of novel antidiabetic thiazolidinedione, T-174, in animal models of non-insulin-dependent diabetes mellitus (NIDDM) and in cultured muscle cells. Br J Pharmacol 125: 429-436

71. Willson TM, Cobb JE, Cowan DJ et al. (1996) The structure-activity relationship between peroxisome proliferatoractivated receptor $\gamma$ agonism and antihyperglycemic activity of thiazolidinediones. J Med Chem 39: 665-668

72. Murakami K, Tobe K, Ide T et al. (1998) A novel insulin sensitizer acts as a coligand for peroxisome proliferator-activated receptor- $\alpha$ (PPAR- $\alpha)$ and PPAR $\gamma$. Effect of PPAR $\alpha$ activation on abnormal lipid metabolism in liver of Zucker fatty rats. Diabetes 47: 1841-1847

73. Shibata T, Matsui K, Nagao K, Shinaki H, Yonemori F, Wakitani K (1999) Pharmacological profiles of a novel oral antidiabetic agent, JTT-501, an isoxazolidinedione derivative. Eur J Pharmacol 364: 211-219
74. Shibata T, Takeuchi S, Yokota S, Kakimoto K, Yonemori F, Wakitani K (2000) Effects of peroxisome proliferator-activated receptor- $\alpha$ and $-\gamma$ agonist, JTT-501, on diabetic complications in Zucker diabetic fatty rats. $\mathrm{Br} \mathrm{J}$ Pharmacol 130: 495-504

75. Brown KK, Henke BR, Blanchard SG et al. (1999) A novel $\mathrm{N}$-aryl tyrosine activator of peroxisome proliferator-activated receptor- $\gamma$ reverses the diabetic phenotype of the Zucker diabetic fatty rat. Diabetes 48: 1415-1424

76. Cobb JE, Henke BR, Blanchard SG (2000) Discovery and in vitro characterization of the novel, tyrosine-based, nonthiazolidinedione PPAR $\gamma$ agonist GI262570. Diabetologia 43 [Suppl 1]: A189 (Abstract)

77. Harrington WW, Hashim M, Faison W, Oliver W, Binz J, Brown KK (2000) Antidiabetic efficacy of GI262570 in rodent models of Type II diabetes. Diabetologia 43 [Suppl 1]: A67 (Abstract)

78. Mukherjee R, Davies PJA, Crombie DL et al. (1997) Sensitization of diabetic and obese mice to insulin by retinoid $\mathrm{X}$ receptor agonists. Nature 386: 407-410

79. Lenhard JM, Lancaster ME, Paulik MA et al. (1999) The RXR agonist LG100268 causes hepatomegaly, improves glycaemic control and decreases cardiovascular risk and cachexia in diabetic mice suffering from pancreatic betacell dysfunction. Diabetologia 42: 545-554

80. Vikramadithyan RK, Chakrabarti R, Misra P et al. (2000) Euglycemic and hypolipidemic activity of PAT5A: a unique thiazolidinedione with weak peroxisome proliferator activated receptor gamma activity. Metabolism 49: 1417-1424

81. Shimaya A, Kurosaki E, Nakano R, Hirayama R, Shibasaki M, Shikama H (2000) The novel hypoglycemic agent YM440 normalizes hyperglycemia without changing body fat weight in diabetic $\mathrm{db} / \mathrm{db}$ mice. Metabolism 49: 411-417

82. Upton R, Widdowson PS, Ishii S, Tanaka H, Williams G (1998) Improved metabolic status and insulin sensitivity in obese fatty (fa/fa) Zucker rats and Zucker Diabetic Fatty (ZDF) rats treated with the thiazolidinedione, MCC-555. Br J Pharmacol 125: 1708-1714

83. Nugent C, Prins JB, Whitehead JP et al. (2001) Potentiation of glucose uptake in 3T3-L1 adipocytes by PPAR $\gamma$ agonists is maintained in cells expressing a PPAR $\gamma$ dominantnegative mutant: evidence for selectivity in the downstream responses to PPAR $\gamma$ activation. Mol Endocrinol 15: 1729-1738

84. Burger HG (2000) Selective oestrogen receptor modulators. Horm Res 53 [Suppl 3]: 25-29

85. Kodera Y, Takeyama K, Murayama A, Suzawa M, Masuhiro Y, Kato S (2000) Ligand type-specific interactions of peroxisome proliferator-activated receptor $\gamma$ with transcriptional coactivators. J Biol Chem 275: 33201-33204

86. Camp HS, Li O, Wise SC et al. (2000) Differential activation of peroxisome proliferator-activated receptor- $\gamma$ by troglitazone and rosiglitazone. Diabetes 49: 539-547

87. Burant CF, Sreenan S, Hirano K et al. (1997) Troglitazone action is independent of adipose tissue. J Clin Invest 100: 2900-2908

88. Arioglu E, Duncan-Morin J, Sebring N et al. (2000) Efficacy and safety of troglitazone in the treatment of lipodystrophy syndromes. Ann Intern Med 133: 263-274

89. Chao L, Marcus-Samuels B, Mason MM et al. (2000) Adipose tissue is required for the antidiabetic, but not for the hypolipidemic, effect of thiazolidinediones. J Clin Invest 106: 1221-1228

90. Kahn CR, Chen L, Cohen SE (2000) Unraveling the mechanism of action of thiazolidinediones. J Clin Invest 106: 1305-1307 
91. Stevenson RW, Hutson NJ, Krupp MN et al. (1990) Actions of novel antidiabetic agent englitazone in hyperglycemic hyperinsulinemic ob/ob mice. Diabetes 39: 12181227

92. Petersen KF, Krssak M, Inzucchi S, Cline GW, Dufour S, Shulman GI (2000) Mechanism of troglitazone action in type 2 diabetes. Diabetes 49: 827-831

93. Roden M, Krssak M, Stingl H et al. (1999) Rapid impairment of skeletal muscle glucose transport/phosphorylation by free fatty acids in humans. Diabetes 48: 358-364

94. Waldhäusl WK, Roden M (2000) The effects of free fatty acids on glucose transport and phosphorylation in human skeletal muscle. Curr Opin Endocrinol Diabetes 7: 211216

95. Boden G (1996) Role of fatty acids in the pathogenesis of insulin resistance and NIDDM. Diabetes 45: 3-10

96. Thompson AL, Lim-Fraser MY, Kraegen EW, Cooney GJ (2000) Effects of individual fatty acids on glucose uptake and glycogen synthesis in soleus muscle in vitro. Am J Physiol: E577-E584

97. Yamauchi T, Kamon J, Waki H et al. (2001) The mechanisms by which both heterozygous peroxisome proliferator-activated receptor $\gamma$ (PPAR $\gamma$ ) deficiency and PPAR $\gamma$ agonist improve insulin resistance. J Biol Chem 276: 41245-41254

98. Yamauchi T, Kamon J, Waki H et al. (2001) The fatderived hormone adiponectin reverses insulin resistance associated with both lipoatrophy and obesity. Nat Med 7: 941-946

99. Maeda N, Takahashi M, Funahashi T et al. (2001) PPAR $\gamma$ ligands increase expression and plasma concentrations of adiponectin, an adipose-derived protein. Diabetes 50: 2094-2099

100. Hofmann C, Lorenz K, Braithwaite SS et al. (1994) Altered gene expression for tumor necrosis factor- $\alpha$ and its receptors during drug and dietary modulation of insulin resistance. Endocrinology 134: 264-270

101. Kallen CB, Lazar MA (1996) Antidiabetic thiazolidinediones inhibit leptin (ob) gene expression in 3T3-L1 adipocytes. Proc Natl Acad Sci USA 93: 5793-5796

102. Steppan CM, Bailey ST, Bhat S et al. (2001) The hormone resistin links obesity to diabetes. Nature 409: 307-312

103. Way JM, Görgün CZ, Tong Q et al. (2001) Adipose tissue resistin expression is severely suppressed in obesity and stimulated by peroxisome proliferator-activated receptor $\gamma$ agonists. J Biol Chem 276: 25651-25653

104. Chua SC, Chung WK, Wu-Peng XS et al. (1996) Phenotypes of mouse diabetes and rat fatty due to mutations in the OB (leptin) receptor. Science 271: 994-996

105. Zhang Y, Proenca R, Maffei M, Barone M, Leopold L, Friedman JM (1994) Positional cloning of the mouse obese gene and its human homologue. Nature 372: 425-432

106. Begum N, Ragolia L (1996) Effect of tumor necrosis factor- $\alpha$ on insulin action in cultured skeletal muscle cells. Endocrinology 137: 2441-2446

107. Fürnsinn C, Neschen S, Wagner O, Roden M, Bisschop M, Waldhäusl W (1997) Acute and chronic exposure to tumor necrosis factor- $\alpha$ fails to affect insulin-stimulated glucose metabolism of isolated rat soleus muscle. Endocrinology 138: 2674-2679

108. Nolte LA, Hansen P, Chen MM, Schluter JM, Gulve EA, Holloszy JO (1998) Short-term exposure to tumor necrosis factor- $\alpha$ does not affect insulin-stimulated glucose uptake in skeletal muscle. Diabetes 47: 721-726

109. Berg AH, Combs TB, Du X, Brownlee M, Scherer PE (2001) The adipocyte-secreted protein Acrp30 enhances hepatic insulin action. Nat Med 7: 947-953
110. Fruebis J, Tsao T-S, Javorschi S et al. (2001) Proteolytic cleavage product of $30-\mathrm{kDa}$ adipocyte complement-related protein increases fatty acid oxidation in muscle and causes weight loss in mice. Proc Natl Acad Sci USA 98: 2005-2010

111. Fürnsinn C, Neschen S, Noe C et al. (1997) Acute non-insulin-like stimulation of rat muscle glucose metabolism by troglitazone in vitro. B J Pharmacol 122: 1367-1374

112. Fürnsinn C, Brunmair B, Neschen S, Roden M, Waldhäusl W (2000) Troglitazone directly inhibits $\mathrm{CO}_{2}$ production from glucose and palmitate in isolated rat skeletal muscle. J Pharmacol Exp Ther 293: 487-493

113. Brunmair B, Gras F, Neschen S et al. (2001) Direct thiazolidinedione action on isolated rat skeletal muscle fuel handling is independent of peroxisome proliferatoractivated receptor- $\gamma$-mediated changes in gene expression. Diabetes 50: 2309-2315

114. Kausch C, Krützfeldt J, Witke A et al. (2000) Effects of troglitazone on cellular differentiation, insulin signaling, and muscle glucose metabolism in cultured human skeletal muscle cells. Biochem Biophys Res Commun 280: 664-674

115. Park KS, Ciaraldi TP, Abrams-Carter L, Mudaliar S, Nikoulina SE, Henry RR (1998) Troglitazone regulation of glucose metabolism in human skeletal muscle cultures from obese type II diabetic subjects. J Clin Endocrinol Metab 83: 1636-1643

116. Cha BS, Ciaraldi TP, Carter L et al. (2001) Peroxisome proliferator-activated receptor (PPAR) $\gamma$ and retinoid $\mathrm{X}$ receptor (RXR) agonists have complemetary effects on glucose and lipid metabolism in human skeletal muscle. Diabetologia 44: 444-452

117. Ciaraldi TP, Huber-Knudsen K, Hickman M, Olefsky JM (1995) Regulation of glucose transport in cultured muscle cells by novel hypoglycemic agents. Metabolism 44: 976982

118. El-Kebbi IM, Roser S, Pollet RJ (1994) Regulation of glucose transport by pioglitazone in cultured muscle cells. Metabolism 43: 953-958

119. Yonemitsu S, Nishimura H, Shintani M et al. (2001) Troglitazone induces GLUT4 translocation in L6 myotubes. Diabetes 50: 1093-1101

120. Okuno A, Ikeda K, Shiota M et al. (1997) Acute effect of troglitazone on glucose metabolism in the absence or presence of insulin in perfused rat hindlimb. Metabolism 46: 716-721

121. Brunmair B, Gras F, Lest A, Roden M, Waldhäusl W, Fürnsinn C (2001) Insulin sensitization by prolonged troglitazone exposure of rat skeletal muscle in vitro. Diabetologia 44 [Suppl 1]: A202 (Abstract)

122. Shibukawa A, Sawada T, Nakao C, Izumi T, Nakagawa T (1995) High-performance frontal analysis for the study of protein binding of troglitazone (CS-045) in albumin solution and in human plasma. J Chromatogr A 697: 337-343

123. Liu LS, Tanaka H, Ishii S, Eckel J (1998) The new antidiabetic drug MCC-555 acutely sensitizes insulin signalling in isolated cardiomyocytes. Endocrinology 139: 45314539

124. Kreutter DK, Andrews KM, Gibbs EM, Hutson NJ, Stevenson RW (1990) Insulin-like activity of new antidiabetic agent CP 68722 in 3T3-L1 adipocytes. Diabetes 39: 1414-1419

125. Fürnsinn C, Englisch R, Ebner K, Nowotny P, Vogl C, Waldhäusl W (1996) Insulin-like vs. non-insulin-like stimulation of glucose metabolism by vanadium, tungsten, and selenium compounds in rat muscle. Life Sci 59: 1989-2000 
126. Ihlemann J, Plough T, Hellsten Y, Galbo H (2000) Effects of stimulation frequency on contraction-induced glucose transport in rat skeletal muscle. Am J Physiol 279: E862-E867

127. Brunmair B, Neschen S, Gras F et al. (2000) Metabolic response to anisoosmolarity of rat skeletal muscle in vitro. Horm Metab Res 32: 251-255 (Erratum in: Horm Metab Res 32: 440)

128. Owen MR, Doran E, Halestrap AP (2000) Evidence that metformin exerts its anti-diabetic effects trough inhibition of complex 1 of the mitochiondrial respiratory chain. Biochem J 348: 607-614

129. El-Mir M-Y, Nogueira V, Fontaine E, Avéret N, Rigoulet M, Leverve X (2000) Dimethylbiguanide inhibits cell respiration via an indirect effect targeted on the respiratory chain complex I. J Biol Chem 275: 223-228

130. Lee MK, Olefsky JM (1995) Acute effects of troglitazone on in vivo insulin action in normal rats. Metabolism 44: 1166-1169

131. Ciaraldi TP, Gilmore A, Olefsky JM, Goldberg M, Heidenreich KA (1990) In vitro studies on the action of CS-045, a new antidiabetic agent. Metabolism 39: 10561062

132. Loviscach M, Rehmann N, Carter L et al. (2000) Distribution of peroxisome proliferator-activated receptors (PPARs) in human skeletal muscle and adipose tissue: relation to insulin action. Diabetologia 43: 304-311

133. Raman P, Foster SE, Stokes MC, Strenge JK, Judd RL (1998) Effect of troglitazone (Rezulin) on fructose 2,6bisphosphate concentration and glucose metabolism in isolated rat hepatocytes. Life Sci 62: 89-94

134. Raman P, Judd RL (2000) Role of glucose and insulin in thiazolidinedione-induced alterations in hepatic gluconeogenesis. Eur J Pharmacol 409: 19-29

135. Adams MD, Raman P, Judd RL (1998) Comparative effects of troglitazone and glyburide on gluconeogenesis and glycolysis in the isolated perfused rat liver. Biochem Pharmacol 55: 1915-1920

136. Nishimura Y, Inoue Y, Takeuchi H, Oka Y (1997) Acute effects of pioglitazone on glucose metabolism in perfused rat liver. Acta Diabetol 34: 206-210

137. Fulgencio J-P, Kohl C, Girard J, Pégorier J-P (1996) Troglitazone inhibits fatty acid oxidation and esterification, and gluconeogenesis in isolated hepatocytes from starved rats. Diabetes 45: 1556-1562

138. Preininger K, Stingl H, Englisch R et al. (1999) Acute troglitazone action in perfused rat liver. $\mathrm{Br} \mathrm{J}$ Pharmacol 126: $372-378$

139. Pugazhenthi S, Khandelwal RL (1998) Insulin action on protein phosphatase- 1 activation is enhanced by the antidiabetic agent pioglitazone in cultured diabetic hepatocytes. Mol Cell Biochem 182: 185-191

140. Davies GF, Khandelwal RL, Wu L, Juurlink BH, Roesler WJ (2001) Inhibition of phosphoenolpyruvate carboxykinase (PEPCK) gene expression by troglitazone: a peroxisome proliferator-activated receptor- $\gamma$ (PPAR $\gamma)$ independent, antioxidant-related mechanism. Biochem Pharmacol 62: 1071-1079
141. Memon RA, Tecott LH, Nonogaki K et al. (2000) Upregulation of peroxisome proliferator-activated receptors $($ PPAR- $\alpha$ ) and PPAR- $\gamma$ messenger ribonucleic acid expression in the liver in murine obesity: troglitazone induces expression of PPAR- $\gamma$-responsive adipose tissuespecific genes in the liver of obese diabetic mice. Endocrinology 141: 4021-4031

142. Bedoucha M, Atzpodien E, Boelsterli UA (2001) Diabetic KKAy mice exhibit increased hepatic PPAR $\gamma 1$ gene expression and develop hepatic steatosis upon chronic treatment with antidiabetic thiazolidinediones. J Hepatol 35: $17-23$

143. Weinstock RS, Murray FT, Diani A, Sangani GA, Wachowski MB, Messina JL (1996) Pioglitazone: in vitro effects on rat hepatoma cells and in vivo liver hypertrophy in $\mathrm{KKA}^{\mathrm{y}}$ mice. Pharmacology 54: 169-178

144. Oakes ND, Thalén PG, Jacinto SM, Ljung B (2001) Thiazolidinediones increase plasma-adipose tissue FFA exchange capacity and enhance insulin-mediated control of systemic FFA availability. Diabetes 50: 1158-1165

145. Jia DM, Tabaru A, Akiyama T, Abe S, Otsumi M (2000) Troglitazone prevents fatty changes of the liver in obese diabetic rats. J Gastroenterol Hepatol 15: 11831191

146. Sakamoto J, Kimura H, Moriyama S et al. (2000) Activation of human peroxisome proliferator-activated receptor (PPAR) subtypes by pioglitazone. Biochem Biophys Res Commun 278: 704-711

147. Peters JM, Hennuyer N, Staels B et al. (1997) Alterations in lipoprotein metabolism in peroxisome proliferator-activated receptor- $\alpha$ deficient mice. J Biol Chem 272: 27307-27312

148. Matsui H, Okumura K, Kawakami K, Hibino M, Toki Y, Ito T (1997) Improved insulin sensitivity by bezafibrate in rats. Relationship to fatty acid composition of skeletalmuscle triglycerides. Diabetes 46: 348-353

149. Kobayashi M, Shigeta Y, Hirata Y et al. (1988) Improvement of glucose tolerance in NIDDM by clofibrate. Diabetes Care 11: 495-499

150. Guerre-Millo M, Gervois P, Raspé E et al. (2000) Peroxisome-proliferator-activated receptor $\alpha$ activators improve insulin sensitivity and reduce adiposity. J Biol Chem 275: $16638-16642$

151. Ide T, Nakazawa T, Mochizuki T, Murakami K (2000) Tissue-specific actions of antidiabetic thiazolidinediones on the reduced fatty acid oxidation in skeletal muscle and liver of Zucker diabetic fatty rats. Metabolism 49: 521525

152. Jones SA, Moore LB, Shenk JL et al. (2000) The pregnane $\mathrm{X}$ receptor: A promicous xenobiotic receptor that has diverged during evolution. Mol Endocrinol 14: $27-$ 39

153. Morita H, Oki Y, Ito T, Ohishi H, Suzuki S, Nakamura H (2001) Administration of troglitazone, but not pioglitazone, reduces insulin resistance caused by short-term dexamethasone (DXM) treatment by accelerating the metabolism of DXM. Diabetes Care 24: 788-789 